NBSIR 81-2427-1

\title{
Calculations of the Heat Release Rate by Oxygen Consumption for Various Applications
}

U.S. DEPARTMENT OF COMMERCE

National Bureau of Standards

National Engineering Laboratory

Center for Fire Research

Washington, DC 20234
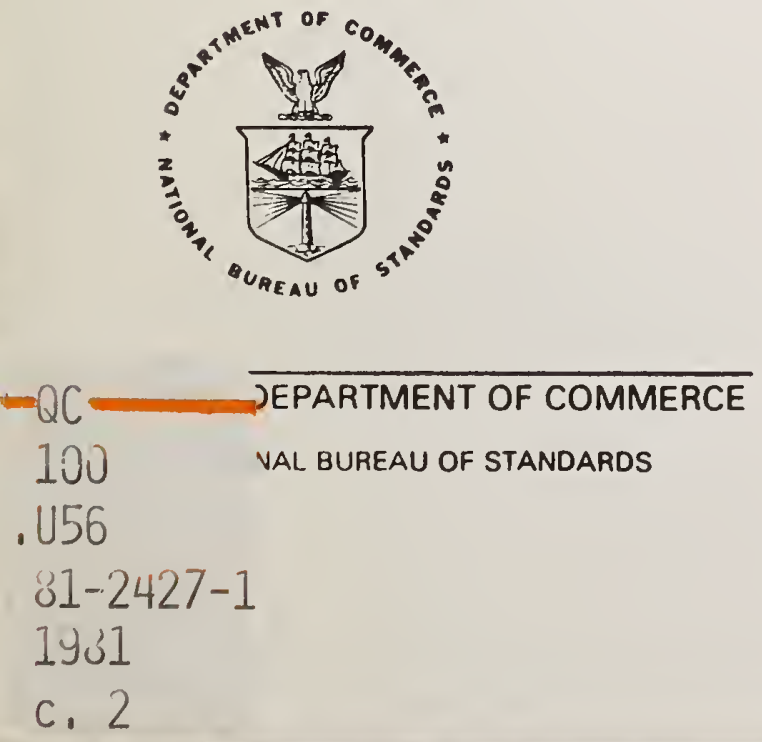

U.S. DEPARTMENT OF COMMERCE

National Bureau of Standards

National Engineering Laboratory

Center for Fire Research

Washington, DC 20234

Issued March 1982

U.S. DEPARTMENT OF COMMERCE, Malcolm Baldrige, Secretary NATIONAL BUREAU OF STANDARDS, Ernest Ambler, Director 

TABLE OF CONTENTS

Page

LIST OF TABLES . . . . . . . . . . . . . . . . . iv

Abstract . . . . . . . . . . . . . . . . . 1

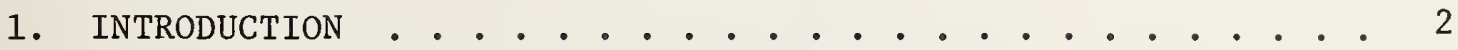

2. GENERAL FORMULA FOR RATE OF HEAT PRODUCTION . . . . . . . 4

3. OXYGEN DEPLETION ..................... . . 9

4. EFFECT OF NEGLECTING CARBON MONOXIDE PRODUCTION . . . . 12

5. RELATIVE HUMIDITY . . . . . . . . . . . . 14

6. VOLUME FLOW RATE INTO SYSTEM . . . . . . . . . . . 15

7. WATER VAPOR ANALYZER IN AIR FLOW DETERMINATION . . . . . 21

8. TRACER GAS IN AIR FLOW DETERMINATION . . . . . . . . 23

9. COMPLETELY DEPLETED AIR . . . . . . . . . . . . 24

10. HIGH TEMPERATURE OXYGEN CELL . . . . . . . . . . . 28

11. SIMPLIFICATIONS . . . . . . . . . . . . 30

12. SUMMARY . . . . . . . . . . . . 32

13. REFERENCES. . . . . . . . . . . . . 35

14. NOMENCLATURE. . . . . . . . . . . . . . . 36 


\section{LIST OF TABLES}

Page

Table 1. Equations to be Used for Various Applications . . . . 38 
CALCULATIONS OF THE HEAT RELEASE RATE BY OXYGEN CONSUMPTION FOR VARIOUS APPLICATIONS

W. J. Parker

Abstract

The oxygen consumption technique is emerging as a powerful tool for determining the heat release rate in a number of diverse fire test applications, including room fire tests, fire endurance tests, the ASTM E 84 tunnel test, and various heat release rate calorimeters. Depending upon the constraints of the test, the accuracy required, the availability of instrumentation and computational facilities, and the willingness to put up with experimental inconveniences, a number of instrumentation options have been considered--each of which require different calculational procedures. The purpose of this report is to develop the equations in a general way and show how to adapt them to various applications such as: closed systems versus open systems; trapping carbon dioxide before it reaches the oxygen analyzer, measuring it, or assuming that it is equal to the reduction in oxygen concentration; ignoring carbon monoxide or measuring it; accounting for the density of the exhaust gases or assuming that it is the same as for air; using a high temperature oxygen cell which measures the oxygen concentration in the exhaust duct directly or a paramagnetic analyzer 
for which corrections must be made for water vapor trapping; taking into account or ignoring the ambient concentration of water vapor and carbon dioxide; and improving the accuracy for open systems by monitoring the water vapor in the exhaust duct. The equations developed here should be useful to anyone setting up a new system and will provide a means of calculating the errors which might be expected when simplified procedures are used.

Key Words: calorimeters; fire tests; heat release rate; oxygen consumption; room fires.

\section{INTRODUCTION}

Experiments in the Steiner tunnel by Parker [1] ${ }^{1}$, in reduced- and full-scale room fire tests by Sensenig [2], and in the OSU Heat Release Rate Calorimeter by Krause and Gann [3] have demonstrated the usefulness of oxygen consumption measurements for determining the heat release rate of burning materials in a variety of applications. It has been established that, to a reasonable engineering approximation, the burning of the materials normally used in the construction and furnishing of rooms will yield a nearly constant value, E, of heat produced per unit mass of oxygen consumed, where $E=13.1 \mathrm{MJ} / \mathrm{kg}$. This value is based on calculations on a large number of polymeric and natural materials by Huggett [4]. By measuring the rate of oxygen consumption in a room fire, we have at

\footnotetext{
$1_{\text {Numbers in brackets }}$ refer to the literature references listed at the end of this report. 
disposal for the first time a practical method of determining the total rate of heat production. To the first approximation, the rate of oxygen consumption is determined by the product of the volumetric flow rate in the exhaust duct reduced to standard conditions and the decrease in the oxygen concentration. However, the standard volume flow rate in the duct which carries off the exhaust gases from the room or the calorimeter is in general larger than the standard volume flow rate of air into the system because of the combustion reactions $\left(\mathrm{e} . \mathrm{g} \cdot, \mathrm{C}_{6} \mathrm{H}_{10} \mathrm{O}_{5}+\right.$ $6 \mathrm{O}_{2} \rightarrow 6 \mathrm{CO}_{2}+5 \mathrm{H}_{2} \mathrm{O}$ ) which generally increase the molar flow rate. Furthermore, the oxygen concentration in the exhaust duct may not be the same as that in the oxygen analyzer because of the trapping out of species such as water and $\mathrm{CO}_{2}$ in the sampling line. This report serves to establish a second order of approximation for the calculation of heat release by oxygen consumption by taking into account these two factors, as well as the effects of $\mathrm{CO}$ production, variation in density of the exhaust gases, and the relative humidity and vitiation of the incoming air. Also developed are the equations to be used when a high temperature oxygen cell or a water vapor analyzer is used to monitor the exhaust gases.

The equations fot heat release rate by oxygen consumption are developed in a genéral way which accounts for vitiated and humid incoming air and with $\mathrm{H}_{2} \mathrm{O}, \mathrm{CO}_{2}, \mathrm{CO}$, and $\mathrm{N}_{2}$ as well as water soluble gases such as $\mathrm{HCl}$ and $\mathrm{HCN}$ as the combustion products. It is then shown how these equations can be simplified for specific applications. For example, there are open systems in which the combustion products along with 
their entrained air are collected by a canopy hood and the total amount of air flowing into the system must be estimated from the volume flow rates measured in the exhaust duct. In addition there are closed systems in which the combustion takes place in a chamber with an exhaust duct and an air supply duct where the rate of air inflow can be accurately measured. In some cases, the $\mathrm{CO}$ in the exhaust duct and water vapor and $\mathrm{CO}_{2}$ in the incoming air can be neglected. Carbon dioxide may be trapped out of the sampling line or it may be measured. While water vapor measurements in the exhaust duct are not normally made, they would improve the accuracy of the technique. There are oxygen analyzers which operate at high temperature which can measure the actual concentration of oxygen in the exhaust gases, while most of the analyzers measure oxygen in a cold gas from which the water and sometimes the $\mathrm{CO}_{2}$ are removed. This report addresses all of these applications.

\section{GENERAL FORMULA FOR RATE OF HEAT PRODUCTION}

While the equations will be developed for the open system, the equations for the closed system will appear as a special case. For the room fire, which exemplifies the open system, it will be assumed that the hood will collect all of the exhaust gases from the room plus an arbitrary amount of entrained air. The total volume flow rate of air into the system (i.e., the airflow into the room plus the air entrained

into the exhaust duct) will be designated as $\dot{\mathrm{V}}_{\mathrm{A}}$ and will be referred to standard conditions. The volume flow rate of combustion products and external air through the exhaust duct, referred to standard conditions, 
will be designated $\mathrm{V}_{\mathrm{S}}$. It is assumed that the water, as well as $\mathrm{HCl}$, $\mathrm{HCN}$, and other gases soluable in water, are trapped out in the sampling line, and that $\mathrm{N}_{2}, \mathrm{O}_{2}, \mathrm{CO}$, and $\mathrm{CO}_{2}$ are the only gases that reach the oxygen analyzer. It is assumed that the components of the incoming air are nitrogen, oxygen, carbon dioxide, and water vapor. The concentrations of all other species such as argon will be included in the concentration of nitrogen.

Let $\mathrm{n}_{\mathrm{N}_{2}}^{\circ}, \mathrm{n}_{\mathrm{O}_{2}}^{\circ}, \mathrm{n}_{\mathrm{CO}_{2}}^{\circ}$, and $\mathrm{n}_{\mathrm{H}_{2} \mathrm{O}}^{\circ}$ be the molar flow rates of nitrogen, oxygen, carbon dioxide, and water vapor into the system. Let $\mathrm{n}_{\mathrm{O}_{2}}^{\mathrm{s}}$, $\mathrm{n}_{\mathrm{N}_{2}}^{\circ}, \mathrm{n}_{\mathrm{CO}}^{\mathrm{s}}, \mathrm{n}_{\mathrm{CO}_{2}}^{\mathrm{s}}$, and $\mathrm{n}_{\mathrm{H}_{2} \mathrm{O}}^{\mathrm{s}}$ be the molar flow of oxygen, nitrogen, carbon monoxide, and carbon dioxide in the exhaust duct. The mole fractions of the incoming gases are:

$$
\begin{aligned}
& \mathrm{x}_{\mathrm{O}_{2}}^{\circ}=\frac{\mathrm{n}_{\mathrm{O}_{2}}^{\circ}}{\mathrm{n}_{\mathrm{N}_{2}}^{\circ}+\mathrm{n}_{\mathrm{O}_{2}}^{\circ}+\mathrm{n}_{\mathrm{CO}_{2}}^{\circ}+\mathrm{n}_{\mathrm{H}_{2} \mathrm{O}}^{\circ}} \\
& \mathrm{x}_{\mathrm{N}_{2}}^{\circ}=\frac{{ }_{\mathrm{N}_{2}}^{\circ}}{\mathrm{n}_{\mathrm{N}_{2}}^{\circ}+\mathrm{n}_{\mathrm{O}_{2}}^{\circ}+\mathrm{n}_{\mathrm{CO}}^{\circ}+\mathrm{n}_{\mathrm{H}_{2} \mathrm{O}}^{\circ}} \\
& \mathrm{x}_{\mathrm{CO}_{2}}^{\circ}=\frac{\mathrm{n}_{\mathrm{CO}}^{\circ}}{\mathrm{n}_{\mathrm{N}_{2}}^{\circ}+\mathrm{n}_{\mathrm{O}_{2}}^{\circ}+\mathrm{n}_{\mathrm{CO}}^{\circ}+\mathrm{n}_{\mathrm{H}_{2} \mathrm{O}}^{\circ}} \\
& \mathrm{x}_{\mathrm{H}_{2} \mathrm{O}}^{\circ}=\frac{\mathrm{n}_{\mathrm{H}_{2} \mathrm{O}}^{\circ}}{\mathrm{n}_{\mathrm{N}_{2}}^{\circ}+\mathrm{n}_{\mathrm{O}_{2}}^{\circ}+\mathrm{n}_{\mathrm{CO}}^{\circ}+\mathrm{n}_{\mathrm{H}_{2} \mathrm{O}}^{\circ}}
\end{aligned}
$$


Since all of the gases are represented

$$
\mathrm{x}_{\mathrm{O}_{2}}^{\circ}+\mathrm{x}_{\mathrm{N}_{2}}^{\circ}+\mathrm{x}_{\mathrm{CO}_{2}}^{\circ}+\mathrm{x}_{\mathrm{H}_{2} \mathrm{O}}^{\circ}=1
$$

If it is assumed that the molar flow rates of $\mathrm{N}_{2}, \mathrm{O}_{2}, \mathrm{CO}_{2}$, and $\mathrm{CO}$ are in the same ratio to each other in the analyzer as they are in the exhaust duct, the mole fractions in the analyzers are:

$$
\begin{aligned}
& \mathrm{x}_{\mathrm{CO}_{2}}^{\mathrm{A}}=\frac{\mathrm{n}_{\mathrm{CO}_{2}}^{\mathrm{s}}}{\mathrm{n}_{\mathrm{N}_{2}}^{\circ}+\mathrm{n}_{\mathrm{O}_{2}}^{\mathrm{s}}+\mathrm{n}_{\mathrm{CO}}^{\mathrm{s}}+\mathrm{n}_{\mathrm{CO}}^{\mathrm{s}}} \\
& \mathrm{x}_{\mathrm{CO}}^{\mathrm{A}}=\frac{\mathrm{n}_{\mathrm{CO}}^{\mathrm{s}}}{\mathrm{x}_{\mathrm{O}_{2}}^{\mathrm{A}}=\frac{\mathrm{n}_{\mathrm{N}_{2}}^{\circ}+\mathrm{n}_{\mathrm{O}_{2}}^{\mathrm{s}}+\mathrm{n}_{\mathrm{CO}}^{\mathrm{s}}+\mathrm{n}_{\mathrm{CO}}^{\mathrm{s}}}{\mathrm{n}_{\mathrm{N}_{2}}^{\circ}+\mathrm{n}_{\mathrm{O}_{2}}^{\mathrm{s}}+\mathrm{n}_{\mathrm{CO}}^{\mathrm{s}}+\mathrm{n}_{\mathrm{CO}}^{\mathrm{s}}}}
\end{aligned}
$$

Making use of equation 1 , the volume flow rate of air into the system referred to standard conditions is given by

$$
\dot{\mathrm{v}}_{\mathrm{A}}=\left(\mathrm{n}_{\mathrm{N}_{2}}^{\circ}+\mathrm{n}_{\mathrm{O}_{2}}^{\circ}+\mathrm{n}_{\mathrm{CO}_{2}}^{\circ}+\mathrm{n}_{\mathrm{H}_{2} \mathrm{O}}^{\circ}\right) \frac{\mathrm{W}_{\mathrm{AIR}}}{\rho_{\mathrm{o}}}=\frac{\mathrm{n}_{\mathrm{O}_{2}}^{\circ}}{\mathrm{x}_{\mathrm{O}_{2}}^{\circ}} \frac{\mathrm{w}_{\mathrm{AIR}}}{\rho_{\mathrm{o}}}
$$

where $W_{A I R}$ is the mass of one gram mole of air and $\rho_{0}$ is the density of air under standard conditions. The oxygen depletion can be defined by

$$
\emptyset \equiv \frac{\mathrm{n}_{\mathrm{O}_{2}}^{\circ}-\mathrm{n}_{\mathrm{O}_{2}}^{\mathrm{s}}}{\mathrm{n}_{\mathrm{O}_{2}}^{\circ}}
$$


The rate of heat production is given by

$$
\dot{\mathrm{Q}}=\mathrm{E}\left(\mathrm{n}_{\mathrm{O}_{2}}^{\circ}-\mathrm{n}_{\mathrm{O}_{2}}^{\mathrm{s}}\right) \mathrm{W}_{\mathrm{O}_{2}}=\mathrm{E} \emptyset \mathrm{n}_{\mathrm{O}_{2}}^{\circ} \mathrm{W}_{\mathrm{O}_{2}}
$$

where $\mathrm{W}_{\mathrm{O}_{2}}$ is the mass of one gram mole of oxygen. Combining equations (9) and (11)

$$
\dot{\mathrm{Q}}=\mathrm{E}_{\mathrm{o}} \frac{\mathrm{W}_{2}}{\mathrm{~W}_{\mathrm{AIR}}} \mathrm{X}_{\mathrm{O}_{2}}^{\circ} \dot{\phi \mathrm{V}_{A}}
$$

Let the net heat of combustion per unit volume of oxygen consumed be

$$
E^{\prime} \equiv E \rho_{0} W_{O_{2}} / \mathrm{W}_{\mathrm{AIR}}=17.2 \mathrm{MJ} / \mathrm{m}^{3}
$$

where $\mathrm{E}=13.1 \mathrm{MJ} / \mathrm{kg}$, where the reactants and products are at $25^{\circ} \mathrm{C}$, $\mathrm{W}_{\mathrm{O}_{2}}=0.032 \mathrm{~kg} / \mathrm{mole}, \mathrm{W}_{\mathrm{AIR}}=0.0290 \mathrm{~kg} / \mathrm{mole}$ based on normal dry air, and $\rho_{0}=1.19 \mathrm{~kg} / \mathrm{m}^{3}$ at $25^{\circ} \mathrm{C}, 760 \mathrm{~mm} \mathrm{Hg}$ based on normal dry air.

Then the formula for the rate of heat production in the case of complete combustion is given by

$$
\dot{Q}=E^{\prime} X_{O_{2}^{\circ}} \dot{V}_{A}
$$

Now consider the case of incomplete combustion where a fraction, $f$, of the oxygen consumed goes into CO production. In order to burn off the $\mathrm{CO}$ to $\mathrm{CO}_{2}$ an additional fraction, $\mathrm{f}$, of the original oxygen consumed would be required. Then the total rate of oxygen consumption for 
complete combustion would have had to increase by the factor $(1+f)$ and the heat release rate would have been

$$
\dot{\mathrm{Q}}_{\text {comp }}=\mathrm{E}^{\prime}(1+\mathrm{f}) \emptyset \mathrm{x}_{\mathrm{O}_{2}}^{\circ} \dot{\mathrm{V}}_{\mathrm{A}}
$$

where $\emptyset$ and $\dot{\mathrm{V}}_{\mathrm{A}}$ are the actual measured values. Since the additional heat produced by burning the $\mathrm{CO}$ to $\mathrm{CO}_{2}$ would have been

$$
\dot{\mathrm{Q}}_{\mathrm{CO}}=\mathrm{fE}^{\prime \prime} \phi \mathrm{x}_{\mathrm{O}_{2}}^{\circ} \dot{\mathrm{V}}_{\mathrm{A}}
$$

the actual heat release rate during incomplete combustion would be

$$
\begin{aligned}
& \dot{Q}=\dot{Q}_{c o m p}-\dot{Q}_{C O}=\left[E^{\prime}(1+f)-E^{\prime \prime} f\right] X_{O_{2}}^{\circ} \phi \dot{V}_{A} \\
& \dot{Q}=\left[E^{\prime}-f\left(E^{\prime \prime}-E^{\prime}\right)\right] \mathrm{X}_{0_{2}}^{\circ} \phi \dot{V}_{A}
\end{aligned}
$$

The difference in the heat of formation of $\mathrm{CO}$ and $\mathrm{CO}_{2}$ is $283 \mathrm{~kJ} /$ mole. Therefore, there is a heat release of $566 \mathrm{~kJ} / \mathrm{mole}$ of $\mathrm{O}_{2}$ consumed in the burning of $\mathrm{CO}$. The heat release per volume of $\mathrm{O}_{2}$ consumed in the burning of $\mathrm{CO}, \mathrm{E}^{\prime \prime}$, is $23.1 \mathrm{MJ} / \mathrm{m}^{3}$ referred to $25^{\circ} \mathrm{C}$.

The fraction $\mathrm{f}$ is given by

$$
f=\frac{n_{\mathrm{CO}}^{\mathrm{s}} / 2}{\mathrm{n}_{\mathrm{O}_{2}}^{\circ}-\mathrm{n}_{\mathrm{O}_{2}}^{\mathrm{s}}}
$$


Using equations (7), (8), and (10),

$$
f=\frac{1-\emptyset}{2 \emptyset} \frac{x_{C O}^{A}}{x_{O_{2}}^{A}}
$$

Substituting equation (16) into equation (14), the general formula for the rate of heat release is given by

$$
\dot{Q}=\left(\varnothing-\left(\frac{E^{\prime \prime}-E^{\prime}}{E^{\prime}}\right)\left(\frac{1-\varnothing}{2}\right) \frac{X_{C O}^{A}}{X_{O_{2}}^{A}}\right) E^{\prime} X_{O_{2}}^{\circ} \quad \dot{V}_{A}
$$

which reduces to equation (13) when $\mathrm{x}_{\mathrm{CO}}^{\mathrm{A}}=0$,

The indeterminate $(1-\emptyset) / \mathrm{x}_{2}^{\mathrm{A}}$ which occurs in equation (17) when the oxygen is completely consumed will be discussed in section 9.

\section{OXYGEN DEPLETION}

In this section, the expression for the oxygen depletion, $\phi$, to be substituted into equations (13) or (17) will be derived.

Adding equations (6) and (7),

$$
x_{\mathrm{CO}_{2}}^{\mathrm{A}}+\mathrm{x}_{\mathrm{CO}}^{\mathrm{A}}=\frac{\mathrm{n}_{\mathrm{CO}_{2}}^{\mathrm{s}}+\mathrm{n}_{\mathrm{CO}}^{\mathrm{s}}}{\mathrm{n}_{\mathrm{N}_{2}}^{\circ}+\mathrm{n}_{\mathrm{O}_{2}}^{\mathrm{s}}+\mathrm{n}_{\mathrm{CO}}^{\mathrm{s}}+\mathrm{n}_{\mathrm{CO}}^{\mathrm{s}}}
$$


Eliminating $\mathrm{n}_{\mathrm{CO}_{2}}+\mathrm{n}_{\mathrm{CO}}$ from equations (8) and (18),

$$
\mathrm{n}_{2}^{\mathrm{s}}=\frac{\mathrm{x}_{\mathrm{O}_{2}}^{\mathrm{A}} \mathrm{n}_{\mathrm{N}_{2}}^{\circ}}{1-\mathrm{x}_{\mathrm{O}_{2}}^{\mathrm{A}}-\mathrm{x}_{\mathrm{CO}_{2}}^{\mathrm{A}}-\mathrm{x}_{\mathrm{CO}}^{\mathrm{A}}}
$$

Equation (10) can be written

$$
\emptyset=1-\frac{1-\mathrm{x}_{2}^{\circ}-\mathrm{x}_{\mathrm{CO}_{2}}^{\circ}-\mathrm{x}_{\mathrm{H}_{2} \mathrm{O}}^{\circ}}{\mathrm{x}_{\mathrm{O}_{2}}^{\circ}} \frac{\mathrm{n}_{2}^{\mathrm{s}}}{\mathrm{n}_{\mathrm{N}_{2}}^{\circ}}
$$

Combining equations (19) and (20)

$$
\emptyset=\frac{\mathrm{x}_{2}^{\circ}-\mathrm{x}_{\mathrm{O}_{2}}^{\mathrm{A}}\left(1-\mathrm{x}_{\mathrm{CO}_{2}}^{\circ}-\mathrm{x}_{\mathrm{H}_{2} \mathrm{O}}^{\circ}\right) /\left(1-\mathrm{x}_{\mathrm{CO}}^{\mathrm{A}}-\mathrm{x}_{\mathrm{CO}}^{\mathrm{A}}\right)}{\mathrm{x}_{\mathrm{O}_{2}}^{\circ}\left(1-\mathrm{x}_{\mathrm{O}_{2}}^{\mathrm{A}} /\left(1-\mathrm{x}_{\mathrm{CO}}^{\mathrm{A}}-\mathrm{x}_{\mathrm{CO}}^{\mathrm{A}}\right)\right)}
$$

The initial concentrations $\mathrm{x}_{\mathrm{O}_{2}}^{\circ}$ and $\mathrm{x}_{\mathrm{CO}_{2}}^{\circ}$ refer to the incoming air. However, the initial (baseline) values in the analyzer prior to the test are generally for dry air since the water vapor has been trapped out. Let $\mathrm{X}_{\mathrm{O}_{2}}^{\circ}$ and $\mathrm{X}_{\mathrm{CO}_{2}}^{\circ}$ be the initial concentrations in the analyzer

$$
\begin{aligned}
& \mathrm{x}_{\mathrm{O}_{2}}^{\mathrm{A}^{\circ}}=\frac{\mathrm{n}_{\mathrm{O}_{2}}^{\circ}}{\mathrm{n}_{\mathrm{O}_{2}}^{\circ}+\mathrm{n}_{\mathrm{N}_{2}}^{\circ}+\mathrm{n}_{\mathrm{CO}_{2}}^{\circ}} \\
& \mathrm{x}_{\mathrm{CO}_{2}^{\circ}}^{\mathrm{\circ}^{\circ}}=\frac{\mathrm{n}_{\mathrm{CO}_{2}}^{\circ}}{\mathrm{n}_{\mathrm{O}_{2}}^{\circ}+\mathrm{n}_{\mathrm{N}_{2}}^{\circ}+\mathrm{n}_{\mathrm{CO}}^{\circ}}
\end{aligned}
$$


Combining equations (1), (3), (4), (22), and (23)

$$
\begin{aligned}
& \mathrm{x}_{2}^{\circ}=\mathrm{x}_{\mathrm{O}_{2}}^{\mathrm{A}^{\circ}}\left(1-\mathrm{x}_{\mathrm{H}_{2} \mathrm{O}}^{\circ}\right) \\
& \mathrm{x}_{\mathrm{CO}_{2}}^{\circ}=\mathrm{x}_{\mathrm{CO}_{2}}^{\mathrm{A}^{\circ}}\left(1-\mathrm{x}_{\mathrm{H}_{2} \mathrm{O}}^{\circ}\right)
\end{aligned}
$$

Equations (24) and (25) should be substituted into equation (21) for $\varnothing$ and into equations (13) and (17) for $\dot{Q}$ when water vapor is trapped and carbon dioxide is not. In some applications of the oxygen consumption technique, carbon dioxide is also trapped so that

$$
\mathrm{x}_{2}^{\circ}=\mathrm{x}_{\mathrm{O}_{2}}^{\mathrm{A}^{\circ}}\left(1-\mathrm{x}_{\mathrm{H}_{2} \mathrm{O}}^{\circ}-\mathrm{x}_{\mathrm{CO}_{2}}^{\circ}\right)
$$

In that case, equation (26) should be substituted into equations (13), (17), and (21).

When $\mathrm{CO}_{2}$ is trapped, equation (26) can be substituted into equation (21) where $\mathrm{x}_{\mathrm{CO}_{2}}^{\mathrm{A}}=0$ to yield

$$
\varnothing=\frac{x_{0_{2}}^{A^{\circ}}-\frac{{ }_{0_{2}}^{A}}{1-x_{C O}^{A}}}{x_{0_{2}}^{A^{\circ}}\left(1-\frac{x_{0_{2}}^{A}}{1-X_{C O}^{A}}\right)}
$$


When $\mathrm{CO}_{2}$ is not trapped equations (24) and (25) can be substituted into equation (21) to get

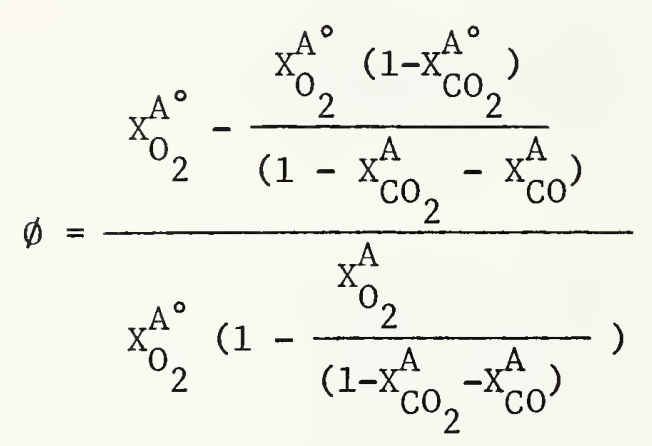

Thus if the initial values of the $\mathrm{O}_{2}$ and $\mathrm{CO}_{2}$ concentrations in the analyzer are used it is not necessary to know the actual concentrations of $\mathrm{CO}_{2}$ and $\mathrm{H}_{2} \mathrm{O}$ in the incoming air to determine $\emptyset$. However, in order to calculate $\dot{Q}$ by equations (13) or (17) it is necessary to determine $\mathrm{x}_{2}^{\circ}$ from (1) either equation (24) or (26) depending on whether $\mathrm{CO}_{2}$ is trapped or not trapped or (2) directly from the analyzer prior to the test with the water vapor and $\mathrm{CO}_{2}$ traps bypassed.

The percentage error in the calculated heat release rate by ignoring the effect of water and carbon dioxide in the incoming air and setting $\mathrm{X}_{\mathrm{O}_{2}}^{\circ} \equiv \mathrm{X}_{\mathrm{O}_{2}}^{\mathrm{A}^{\circ}}$ is by equation (24) and (26) equal to $100 \mathrm{X}_{\mathrm{H}_{2} \mathrm{O}}^{\circ}$ and $100\left(\mathrm{X}_{\mathrm{H}_{2} \mathrm{O}}^{\circ}+\mathrm{X}_{\mathrm{CO}_{2}}^{\circ}\right)$ depending on whether $\mathrm{CO}_{2}$ is trapped or not trapped. For a relative humidity of $50 \%$ at $20^{\circ} \mathrm{C}$ the error due to the neglect of ambient water vapor is only about $1 \%$.

\section{EFFECT OF NEGLECTING CARBON MONOXIDE PRODUCTION}

The oxygen depletion is given by equation 21 . When the moisture and vitiation of the incoming air are neglected and the $\mathrm{CO}_{2}$ is trapped, 
this equation reduces to

$$
\varnothing=\frac{\mathrm{x}_{\mathrm{O}_{2}}^{\circ}-\frac{\mathrm{x}_{\mathrm{O}_{2}}^{\mathrm{A}}}{1-\mathrm{x}_{\mathrm{CO}}^{\mathrm{A}}}}{\mathrm{x}_{\mathrm{O}_{2}}^{\circ}\left(1-\frac{\mathrm{x}_{2}^{\mathrm{A}}}{1-\mathrm{x}_{\mathrm{CO}}^{\mathrm{A}}}\right)}
$$

If the $\mathrm{CO}$ is neglected

$$
\phi *=\frac{\mathrm{x}_{0_{2}}^{\circ}-\mathrm{x}_{\mathrm{O}_{2}}^{\mathrm{A}}}{\mathrm{x}_{\mathrm{O}_{2}}^{\circ}\left(1-\mathrm{x}_{\mathrm{O}_{2}}^{\mathrm{A}}\right)}
$$

The fraction of the depleted oxygen going into co production is given by

$$
f=\frac{1}{2} \frac{x_{C O}^{A}}{x_{O_{2}}^{\circ}-x_{O_{2}}^{A}}
$$

Equation 14 gives the rate of heat production. If $\dot{Q} *$ is the calculated rate of heat production ignoring carbon monoxide then

$$
\frac{\dot{Q}}{\mathrm{Q}^{*}}=\left[1-\mathrm{f}\left(\frac{E^{\prime \prime}-E^{\prime}}{E^{\prime}}\right)\right] \frac{\emptyset}{\phi *}
$$


The percentage error is then given by

$$
\varepsilon=100\left[1-(1-0.343 f) \frac{\emptyset}{\emptyset *}\right]
$$

In a severe room fire $\mathrm{f}$ can be 0.3 while $\mathrm{X}_{\mathrm{CO}}$ is 0.1 . Hence $\varepsilon \sim 40 \%$ If $14 \%$ is taken to be the lowest permissable value for the oxygen concentration in the fire effluent and the $\mathrm{CO}$ is about $1 \%$ then $\mathrm{f}=0.07$ and $\varepsilon \sim 5 \%$.

\section{RELATIVE HUMIDITY}

The volume fraction of water vapor in the incoming air is given by

$$
\mathrm{X}_{\mathrm{H}_{2} \mathrm{O}}^{\circ}=\frac{\mathrm{P}_{\mathrm{H}_{2} \mathrm{O}}}{760} \frac{\mathrm{H}}{100}
$$

where $\mathrm{P}_{\mathrm{H}_{2} \mathrm{O}}$ is the vapor pressure of water in $\mathrm{mm} \mathrm{Hg}$ at the ambient temperature and $\mathrm{H}$ is the relative humidity in percent. The vapor pressure of water is given as a function of temperature in the Handbook of Chemistry and Physics. A partial table is reproduced here. 
Temperature $\left({ }^{\circ} \mathrm{C}\right)$

0

5

10

15

20

25

30

35

40
Water Vapor Pressure (mm Hg)

4.58

6.54

9.21

12.79

17.55

23.78

31.86

42.23

55.40

6. VOLUME FLOW RATE OF AIR INTO SYSTEM

If the volume flow rate of air into the system, $\dot{V}_{A}$, cannot be measured, the volume flow rate in the exhaust duct, $\dot{V}_{s}$, must be measured and a relationship between $\dot{V}_{S}$ and $\dot{V}_{A}$ must be found. $\dot{V}_{S}$ is given by

$$
\dot{\mathrm{V}}_{\mathrm{S}}=(1-\phi) \dot{\mathrm{V}}_{\mathrm{A}}+\alpha \phi \dot{\mathrm{V}}_{\mathrm{A}}
$$

so that 


$$
\dot{\mathrm{V}}_{\mathrm{A}}=\dot{\mathrm{V}}_{\mathrm{S}} /(1+(\alpha-1) \emptyset)
$$

where $\alpha$ is the expansion factor for the fraction of the air that was depleted of its oxygen.

$$
\alpha=\mathrm{X}_{\mathrm{N}_{2}}^{\circ}+\mathrm{X}_{\mathrm{H}_{2} \mathrm{O}}^{\circ}+\mathrm{X}_{\mathrm{CO}_{2}}^{\circ}+\mathrm{BX}_{\mathrm{O}_{2}}^{\circ}=1-\mathrm{X}_{\mathrm{O}_{2}}^{\circ}+\beta \mathrm{X}_{\mathrm{O}_{2}}^{\circ}
$$

where $\beta$ is the ratio of the moles of combustion products formed to the moles of oxygen consumed. The value of $\beta$ is determined from the general reaction:

$$
\begin{gathered}
\mathrm{C}_{a} \mathrm{H}_{b} \mathrm{O}_{c} \mathrm{~N}_{d} \mathrm{X} e+\left(\mathrm{a}-\frac{\mathrm{g}}{2}+\frac{\mathrm{b}-\mathrm{e}}{4}-\frac{\mathrm{c}}{2}\right) \mathrm{O}_{2} \\
\rightarrow(a-g) \mathrm{CO}_{2}+\frac{\mathrm{b}-\mathrm{e}}{2} \mathrm{H}_{2} \mathrm{O}+\mathrm{eHX}+\mathrm{gCO}+\frac{\mathrm{d}}{2} \mathrm{~N}_{2} \\
\beta=\frac{4 a+2 b+2 e+2 d}{4 a+b-e-2 c-2 g}
\end{gathered}
$$

It is assumed that the nitrogen contained in the fuel is released as molecular nitrogen. The symbol $\mathrm{X}$ represents any of the halogens fluorine, chlorine, or bromine. From equation (35) it is seen that if $\mathrm{CO}_{2}$ in the incoming air can be neglected

$$
g=\left(\frac{x_{C O}^{A}}{x_{\mathrm{CO}_{2}}^{A}+x_{C O}^{A}}\right) a
$$

provided that $\mathrm{CO}_{2}$ is not trapped, so that equation (36) can be written 


$$
\beta=\frac{4 a+2 b+2 e+2 d}{\left(4-2 x_{C O}^{A} /\left(x_{C O}^{A}+x_{C O}^{A}\right)\right) a+b-e-2 c}
$$

Equation (38) allows one to correct $\beta$ for carbon monoxide production during the test based on $\mathrm{CO}$ and $\mathrm{CO}_{2}$ measurements in the gas sampling line if the stoichiometric coefficients, a, b, c, d and e are known.

If equation (35) is expanded to include the unreacted components such as $\mathrm{N}_{2}, \mathrm{CO}_{2}$, and $\mathrm{H}_{2} \mathrm{O}$ in the incoming air, the effect of $\mathrm{CO}_{2}$ in the incoming air can be accounted for by the expression

$$
g=\frac{a \emptyset+\frac{\mathrm{x}_{\mathrm{CO}_{2}}^{\circ}}{\mathrm{X}_{\mathrm{O}_{2}}^{\circ}}\left(\mathrm{a}+\frac{\mathrm{b}-\mathrm{e}}{4}-\frac{\mathrm{c}}{2}\right)}{\left(1+\frac{\mathrm{X}_{\mathrm{CO}}^{\mathrm{A}}}{\mathrm{X}_{\mathrm{CO}}^{\mathrm{A}}}\right) \emptyset+\frac{1}{2} \frac{\mathrm{X}_{\mathrm{CO}}^{\circ}}{\mathrm{X}_{\mathrm{O}_{2}}^{\circ}}}
$$

which reduces to equation (37) when the ambient $\mathrm{CO}_{2}$ concentration $\mathrm{X}_{\mathrm{CO}}^{\circ}$ drops to zero. Since $\mathrm{CO}_{2}$ is not trapped

$$
\frac{\mathrm{X}_{\mathrm{CO}_{2}}^{\circ}}{\mathrm{X}_{\mathrm{O}_{2}}^{\circ}}=\frac{\mathrm{X}_{\mathrm{CO}_{2}}^{\mathrm{A}^{\circ}}}{\mathrm{x}_{\mathrm{O}_{2}}^{\mathrm{A}^{\circ}}}
$$

and

$$
\frac{a \emptyset+\frac{\mathrm{X}_{\mathrm{CO}}^{\mathrm{A}_{2}}}{\mathrm{X}_{\mathrm{O}_{2}}^{\mathrm{O}^{\circ}}}\left(\mathrm{a}+\frac{\mathrm{b}-\mathrm{e}}{4}-\frac{c}{2}\right)}{\left(1+\frac{\mathrm{X}_{\mathrm{CO}}^{\mathrm{A}}}{\mathrm{X}_{\mathrm{CO}}^{\mathrm{A}}}\right) \emptyset+\frac{1}{2} \frac{\mathrm{X}_{\mathrm{CO}}^{\mathrm{A}^{\circ}}}{\mathrm{X}_{\mathrm{O}_{2}}^{\mathrm{A}^{\circ}}}}
$$


Let $g^{*}$ be the approximate value given by equation (37) neglecting ambient $\mathrm{CO}_{2} \cdot$ Then

$$
\frac{g}{g^{*}}=1+\frac{\mathrm{X}_{\mathrm{CO}}^{\mathrm{A}^{\circ}}}{\mathrm{X}_{\mathrm{O}_{2}}^{\mathrm{A}^{\circ}}} \frac{1}{\mathrm{a} \emptyset}\left[\mathrm{a}+\frac{\mathrm{b}-\mathrm{e}}{4}-\frac{\mathrm{c}}{2}-\frac{\mathrm{g}}{2}\right]
$$

where the last term represents the fractional error in $\mathrm{g}$ that would occur. Although this fraction could be large for a small depletion $\emptyset$, $g$ is itself very small for low $\emptyset$ so that equation (37) for $g$ should be quite adequate.

Some $\beta$ and $\alpha$ values are listed for a few common materials undergoing complete combustion in normal dry air to the products, $\mathrm{CO}_{2}$, $\mathrm{H}_{2} \mathrm{O}$, and $\mathrm{HCl}$ :

$\beta$

$\begin{array}{lll}\text { Carbon } & 1.0 & 1.00 \\ \text { Hydrogen } & 2.0 & 1.21 \\ \text { Cellulose } & 1.83 & 1.175 \\ \mathrm{CH}_{4} & 1.5 & 1.105 \\ \mathrm{C}_{3} \mathrm{H}_{8} & 1.4 & 1.084 \\ -\mathrm{CH}_{2}- & 1.33 & 1.069 \\ \mathrm{C}_{2} \mathrm{H}_{3} \mathrm{Cl} & 1.6 & 1.126\end{array}$

If we know what is burning, we can specify $\alpha$. If not, we can set $\alpha=1.1$ which is approximately its value for methane. The largest error encountered would then be 10 percent if pure carbon, or charcoal, were burning and the oxygen in the stack were completely consumed $(\emptyset=1)$. 
At the stage of the fire where charcoal was burning one would not expect the depletion in the stack to be large. It should be noted that if charcoal is formed it implies a larger $\alpha$ earlier in the fire due to the water formed in the char-forming process. During vigorous burning the materials would more likely lie between cellulose and $-\mathrm{CH}_{2}$ - and the stack should be required to entrain enough uncombusted air to insure that all of the combustion products are pulled into the stack. Let the maximum value of $\emptyset$ be 0.5 and consider the error for cellulose and $-\mathrm{CH}_{2}-$. For $\alpha-1=0.175$ but using an assumed value of 0.10 the error would be 4 percent. This was determined from the ratio of the air flows in equation (33). For $\alpha-1=0.069$ the error would be 2 percent.

If the gas velocity in the exhaust duct is measured with a pitot static tube or a bidirectional probe, the standard volume flow rate is given by:

$$
\dot{\mathrm{V}}_{\mathrm{S}}=\mathrm{jkA}\left(\frac{2 \Delta \mathrm{P}}{\rho_{\mathrm{o}}} \frac{\mathrm{T}_{\mathrm{o}}}{\mathrm{T}_{\mathrm{S}}}\right)^{1 / 2}=22.4 \mathrm{jkA}\left(\frac{\Delta \mathrm{P}}{\mathrm{T}_{\mathrm{S}}}\right)^{1 / 2} \frac{\mathrm{m}^{3}}{\mathrm{~s}}
$$

where $T_{S}$ is the gas temperature in the duct in $K$ and $\Delta P$ is the pressure differential across the pitot static tube in $\mathrm{Pa}$, $\mathrm{A}$ is the cross sectional area of the duct in $\mathrm{m}^{2}$, $\mathrm{k}$ is the ratio of the average mass flow rate per unit area to the centerline mass flow rate per unit area, and $j$ is a calibration factor equal to unity for a pitot static tube and 0.926 for a bidirectional probe [5]. 
In measuring the volume flow rate in the exhaust duct with a pitot static tube, it is assumed that the density of the exhaust gas $\rho_{s}$ is the same as the density of air $\rho_{0}$ when both are referred to standard conditions. In order to correct for the density difference, the righthand side of equation (42) should be multiplied by $\left(\rho_{o} / \rho_{s}\right)^{1 / 2}$. Let $W_{A I R}$ and $W_{S}$ be the molecular weight of the incoming air and the exhaust gas in $\mathrm{g} / \mathrm{mole}$ so that $\frac{\rho_{\mathrm{o}}}{\rho_{\mathrm{S}}}=\frac{\mathrm{W}_{\mathrm{AIR}}}{\mathrm{W}_{\mathrm{S}}}$.

The weight of one gram mole of the exhaust gases is determined from equation (35).

$$
\begin{aligned}
W_{S}= & (1-\emptyset) W_{A I R}+\emptyset\left[44(a-g)+18 \frac{b-e}{2}+36.4 e+28\left(g+\frac{d}{2}\right)+\right. \\
& \left.28\left(\frac{1-x_{0_{2}}^{\circ}}{x_{0_{2}}^{\circ}}\right)\left(a-\frac{g}{2}+\frac{b-e}{4}-\frac{c}{2}\right)\right] \div\left[a+\frac{b}{2}+\frac{d}{2}+\frac{e}{2}+\frac{\left(1-X_{0_{2}}^{\circ}\right)}{x_{O_{2}}^{\circ}}\right. \\
& \left.\left(a-\frac{g}{2}+\frac{b-e}{4}-\frac{c}{2}\right)\right]
\end{aligned}
$$

and $\mathrm{W}_{\mathrm{AIR}}=0.028\left(1-\mathrm{X}_{\mathrm{O}_{2}}^{\circ}\right)+0.032\left(\mathrm{x}_{\mathrm{O}_{2}}^{\circ}\right)$. It is assumed that the halogen is chlorine. If $\mathrm{X}_{\mathrm{O}_{2}}^{\circ}=0.21, \mathrm{~W}_{\mathrm{AIR}}=0.029 \mathrm{~kg} / \mathrm{mole}$.

For complete burning of cellulose to $\mathrm{CO}_{2}$ and $\mathrm{H}_{2} \mathrm{O}$ and $\emptyset=1$, $W_{S}=0.02907$. Hence, $\left(\frac{\rho_{0}}{\rho_{S}}\right)^{1 / 2}=1.001$ which is negligible correction. Equation (43) assumes the inert component of the air is nitrogen and does not account for humidity. 


\section{WATER VAPOR ANALYZER}

The quantity $B$ in equation (34) represents the expansion of the gases in the exhaust duct due to chemical reactions. If a water vapor analyzer is used to measure the water vapor concentration in the exhaust duct, this concentration along with the oxygen, carbon dioxide, and carbon monoxide measurements in the sampling line where water is trapped can be used to calculate $\beta$ without any assumption concerning the chemical composition of the burning materials. The water vapor concentration $\mathrm{X}_{\mathrm{H}_{2} \mathrm{O}}^{\mathrm{S}}$ is measured in the presence of all of the exhaust duct gases while the other concentrations $\mathrm{x}_{\mathrm{O}_{2}}^{\mathrm{A}}, \mathrm{x}_{\mathrm{CO}_{2}}^{\mathrm{A}}$, and $\mathrm{x}_{\mathrm{CO}}^{\mathrm{A}}$ are measured in the absence of the water vapor. However, for the purposes of the derivation, it is necessary to express all of these concentrations in terms of their values in the exhaust duct.

$$
\begin{aligned}
& \mathrm{x}_{\mathrm{H}_{2} \mathrm{O}}^{\mathrm{s}}=\frac{\mathrm{n}_{\mathrm{H}_{2} \mathrm{O}}^{\mathrm{s}}}{\mathrm{n}_{\mathrm{N}_{2}}^{\circ}+\mathrm{n}_{\mathrm{O}_{2}}^{\mathrm{s}}+\mathrm{n}_{\mathrm{CO}_{2}}^{\mathrm{s}}+\mathrm{n}_{\mathrm{CO}}^{\mathrm{s}}+\mathrm{n}_{\mathrm{H}_{2} \mathrm{O}}^{\mathrm{s}}} \\
& \mathrm{x}_{2}^{\mathrm{s}}=\frac{\mathrm{n}_{\mathrm{O}_{2}}^{\mathrm{s}}}{\mathrm{n}_{\mathrm{N}_{2}}^{\circ}+\mathrm{n}_{\mathrm{O}_{2}}^{\mathrm{s}}+\mathrm{n}_{\mathrm{CO}_{2}}^{\mathrm{s}}+\mathrm{n}_{\mathrm{CO}}^{\mathrm{s}}+\mathrm{n}_{\mathrm{H}_{2} \mathrm{O}}^{\mathrm{s}}} \\
& \mathrm{x}_{2}^{\mathrm{s}}=\frac{\mathrm{n}_{\mathrm{CO}_{2}}^{\mathrm{s}}}{\mathrm{n}_{\mathrm{N}_{2}}^{\circ}+\mathrm{n}_{\mathrm{O}_{2}}^{\mathrm{s}}+\mathrm{n}_{\mathrm{CO}_{2}}^{\mathrm{s}}+\mathrm{n}_{\mathrm{CO}}^{\mathrm{s}}+\mathrm{n}_{\mathrm{H}_{2} \mathrm{O}}^{\mathrm{s}}} \\
& \mathrm{x}_{\mathrm{CO}}^{\mathrm{s}}=\frac{n_{\mathrm{CO}}^{\mathrm{s}}}{\mathrm{n}_{\mathrm{N}_{2}}^{\circ}+\mathrm{n}_{\mathrm{O}_{2}}^{\mathrm{s}}+\mathrm{n}_{\mathrm{CO}}{ }_{2}^{\mathrm{s}}+\mathrm{n}_{\mathrm{CO}}^{\mathrm{s}}+\mathrm{n}_{\mathrm{H}_{2} \mathrm{O}}^{\mathrm{s}}}
\end{aligned}
$$


The expansion factor $\beta$ is given by

$$
\beta=\frac{\mathrm{n}_{\mathrm{H}_{2} \mathrm{O}}^{\mathrm{s}}+\mathrm{n}_{\mathrm{CO}}^{\mathrm{s}}+\mathrm{n}_{\mathrm{CO}}^{\mathrm{s}}}{\mathrm{n}_{\mathrm{O}_{2}}^{\circ}-\mathrm{n}_{\mathrm{O}_{2}}^{\mathrm{s}}}
$$

which with the use of equation (10) can be written

$$
\beta=\left(\frac{1-\phi}{\phi}\right)\left(\frac{\mathrm{n}_{2}^{\mathrm{s}} \mathrm{O}}{\mathrm{n}_{\mathrm{O}_{2}}^{\mathrm{s}}}+\frac{\mathrm{n}_{\mathrm{CO}}^{\mathrm{s}}}{\mathrm{n}_{\mathrm{O}_{2}}^{\mathrm{s}}}+\frac{\mathrm{n}_{\mathrm{CO}}^{\mathrm{s}}}{\mathrm{n}_{\mathrm{O}_{2}}^{\mathrm{s}}}\right)
$$

Using equation (6), (7), (8), (44), and (45)

$$
\beta=\frac{1-\varnothing}{\emptyset}\left(\frac{\mathrm{x}_{\mathrm{H}_{2} \mathrm{O}}^{\mathrm{S}}}{\mathrm{x}_{\mathrm{O}_{2}}^{\mathrm{S}}}+\frac{\mathrm{x}_{\mathrm{CO}_{2}}^{\mathrm{A}}}{\mathrm{x}_{\mathrm{O}_{2}}^{\mathrm{A}}}+\frac{\mathrm{x}_{\mathrm{CO}}^{\mathrm{A}}}{\mathrm{x}_{\mathrm{O}_{2}}^{\mathrm{A}}}\right)
$$

From equation (8), (44), and (45)

$$
\mathrm{x}_{\mathrm{O}_{2}}^{\mathrm{s}}=\mathrm{x}_{\mathrm{O}_{2}}^{\mathrm{A}}\left(1-\mathrm{x}_{\mathrm{H}_{2} \mathrm{O}}^{\mathrm{S}}\right)
$$

Therefore,

$$
\beta=\frac{1-\emptyset}{\emptyset} \frac{1}{\mathrm{X}_{\mathrm{O}_{2}}^{\mathrm{A}}}\left(\frac{\mathrm{X}_{\mathrm{H}_{2} \mathrm{O}}^{\mathrm{S}}}{1-\mathrm{X}_{\mathrm{H}_{2} \mathrm{O}}^{\mathrm{S}}}+\mathrm{x}_{\mathrm{CO}_{2}}^{\mathrm{A}}+\mathrm{x}_{\mathrm{CO}}^{\mathrm{A}}\right)
$$

Then from equations (33), (34), and (52) the volume flow rate into the system is given by

$$
\dot{\mathrm{V}}_{\mathrm{A}}=\dot{\mathrm{V}}_{\mathrm{s}}\left(1-\mathrm{x}_{\mathrm{O}_{2}}^{\circ} \phi+\mathrm{x}_{\mathrm{O}_{2}}^{\circ} \frac{(1-\emptyset)}{\mathrm{x}_{\mathrm{O}_{2}}^{\mathrm{A}}}\left(\mathrm{x}_{\mathrm{CO}_{2}}^{\mathrm{A}}+\mathrm{x}_{\mathrm{CO}}^{\mathrm{A}}+\frac{\mathrm{x}_{\mathrm{H}_{2} \mathrm{O}}^{\mathrm{S}}}{1-\mathrm{x}_{\mathrm{H}_{2} \mathrm{O}}^{\mathrm{s}}}\right)\right)^{-1}
$$

which should be substituted into equations (13) or (17). 


\section{TRACER GAS IN AIR FLOW DETERMINATION}

When the oxygen consumption technique is applied to large existing systems such as fire endurance test furnaces or to large scale test facilities, accurate volumetric flow measurements in the exhaust stack are often difficult. One technique that might be used to overcome this is to introduce a tracer gas into the exhaust duct far enough upstream that mixing is complete by the time that it reaches the gas sampling point.

Let the gas be introduced at a volumetric flow rate of $\dot{V}_{T}$ so that its concentration in the analyzer is $\mathrm{X}_{\mathrm{T}}^{\mathrm{A}}$. The concentration of nitrogen in the analyzer is given by

$$
\mathrm{X}_{\mathrm{N}_{2}}^{\mathrm{A}}=1-\mathrm{X}_{\mathrm{O}_{2}}^{\mathrm{A}}-\mathrm{x}_{\mathrm{CO}}^{\mathrm{A}}-\mathrm{x}_{\mathrm{CO}}^{\mathrm{A}}-\mathrm{X}_{\mathrm{T}} \approx 1-\mathrm{x}_{\mathrm{O}_{2}}^{\mathrm{A}}-\mathrm{X}_{\mathrm{CO}}^{\mathrm{A}}-\mathrm{X}_{\mathrm{CO}}^{\mathrm{A}}
$$

Then the volume flow rate of nitrogen into the system is given by

$$
\frac{\dot{\mathrm{V}}_{\mathrm{N}_{2}}}{\dot{\mathrm{V}}_{\mathrm{T}}}=\frac{1-\mathrm{X}_{\mathrm{O}_{2}}^{\mathrm{A}}-\mathrm{X}_{\mathrm{CO}_{2}}^{\mathrm{A}}-\mathrm{x}_{\mathrm{CO}}^{\mathrm{A}}}{\mathrm{X}_{\mathrm{T}}^{\mathrm{A}}}
$$

The volume flow rate of oxygen into the system is given by

$$
\dot{\mathrm{V}}_{\mathrm{O}_{2}}^{\circ}=\frac{\mathrm{X}_{2}^{\circ}}{\mathrm{X}_{\mathrm{N}_{2}}^{\circ}} \dot{\mathrm{V}}_{\mathrm{N}_{2}}=\dot{\mathrm{V}}_{\mathrm{T}} \frac{\mathrm{X}_{\mathrm{O}_{2}}^{\mathrm{A}^{\circ}}}{\mathrm{X}_{\mathrm{N}_{2}}^{\mathrm{A}^{\circ}}} \frac{\left(1-\mathrm{X}_{\mathrm{O}_{2}}^{\mathrm{A}}-\mathrm{X}_{\mathrm{CO}}^{\mathrm{A}}-\mathrm{X}_{\mathrm{CO}}^{\mathrm{A}}\right)}{\mathrm{X}_{\mathrm{T}}^{\mathrm{A}}}
$$


The volume flow rate of $\mathrm{O}_{2}$ in the duct after combustion is complete is

$$
\frac{\dot{\mathrm{V}}_{\mathrm{O}_{2}}}{\dot{\mathrm{V}}_{\mathrm{T}}}=\frac{\mathrm{X}_{\mathrm{O}_{2}}^{\mathrm{A}}}{\mathrm{X}_{\mathrm{T}}^{\mathrm{A}}}
$$

The heat release rate $Q$ is given by

$$
\begin{aligned}
& \dot{Q}=E^{\prime}\left(V_{O_{2}}^{\circ}-V_{O_{2}}\right)=E^{\prime} \frac{\dot{V}_{T}}{X_{T}^{A}}\left(\frac{\mathrm{X}_{O_{2}}}{\mathrm{X}_{\mathrm{N}_{2}}^{\circ}}\left(1-\mathrm{X}_{\mathrm{O}_{2}}^{\mathrm{A}}-\mathrm{X}_{\mathrm{CO}_{2}}^{\mathrm{A}}-\mathrm{X}_{\mathrm{CO}}^{\mathrm{A}}\right)-\mathrm{X}_{\mathrm{O}_{2}}^{\mathrm{A}}\right) \\
& \dot{\mathrm{Q}}=\mathrm{E}^{\prime} \frac{\dot{V}_{\mathrm{T}}}{\mathrm{X}_{\mathrm{T}}^{\mathrm{A}}}\left(\frac{\mathrm{X}_{\mathrm{O}_{2}}^{\circ}\left(1-\mathrm{X}_{\mathrm{CO}}^{\mathrm{A}}-\mathrm{X}_{\mathrm{CO}}^{\mathrm{A}}\right)-\mathrm{X}_{\mathrm{O}_{2}}}{1-\mathrm{X}_{\mathrm{O}_{2}}}\right)
\end{aligned}
$$

\section{COMPLETELY DEPLETED AIR}

In the case of complete consumption of the oxygen in the incoming air, equations (17) and (53) are indeterminate since $\emptyset=1$ and $\mathrm{x}_{0_{2}}=0$. In that event, it is necessary to solve equation $(21)$ for $(1-\emptyset) / \mathrm{x}_{0_{2}}$ in the limit where $\mathrm{x}_{\mathrm{O}_{2}}^{\mathrm{A}}$ goes to zero. Hence,

$$
\frac{1-\emptyset}{x_{O_{2}}^{A}}=\frac{1-x_{O_{2}}^{\circ}-x_{\mathrm{H}_{2}}^{\circ}-x_{\mathrm{CO}_{2}}^{\circ}}{\mathrm{x}_{\mathrm{O}_{2}}^{\circ}\left(1-\mathrm{x}_{\mathrm{CO}_{2}}^{\mathrm{A}}-\mathrm{x}_{\mathrm{CO}}^{\mathrm{A}}\right)}
$$

for fully depleted air.

Substitution into equation (17) where $\emptyset=1$ yields 


$$
\dot{Q}=\left[\mathrm{X}_{\mathrm{O}_{2}}^{\circ}-\left(\frac{E^{\prime \prime}-E^{\prime}}{E^{\prime}}\right)\left(\frac{1-\mathrm{X}_{\mathrm{O}_{2}}^{\circ}-\mathrm{X}_{\mathrm{H}_{2} \mathrm{O}}^{\circ}-\mathrm{X}_{\mathrm{CO}_{2}}^{\circ}}{1-\mathrm{X}_{\mathrm{CO}_{2}}^{\mathrm{A}}-\mathrm{X}_{\mathrm{CO}}^{\mathrm{A}}}\right) \frac{\mathrm{X}_{\mathrm{CO}}^{\mathrm{A}}}{2}\right] \mathrm{E}^{\prime} \dot{\mathrm{V}}_{\mathrm{A}}
$$

and assuming for now that there is no other unburned fuel than Co, substitution into equation (53) yields

$$
\begin{aligned}
\dot{\mathrm{v}}_{\mathrm{A}}= & \dot{\mathrm{v}}_{\mathrm{s}}\left(1-\mathrm{x}_{\mathrm{O}_{2}}^{\circ}+\frac{\left(1-\mathrm{x}_{\mathrm{O}_{2}}^{\circ}-\mathrm{x}_{\mathrm{H}_{2} \mathrm{O}}^{\circ}-\mathrm{x}_{\mathrm{CO}_{2}}^{\circ}\right)}{\left(1-\mathrm{x}_{\mathrm{CO}_{2}}^{\mathrm{A}}-\mathrm{x}_{\mathrm{CO}}^{\mathrm{A}}\right)}-\left(\mathrm{x}_{\mathrm{CO}_{2}}^{\mathrm{A}}+\mathrm{x}_{\mathrm{CO}}^{\mathrm{A}}+\right.\right. \\
& \left.\left.\frac{\mathrm{x}_{\mathrm{H}_{2} \mathrm{O}}^{\mathrm{s}}}{1-\mathrm{x}_{\mathrm{H}_{2} \mathrm{O}}^{\mathrm{S}}}\right)\right)^{-1}
\end{aligned}
$$

when a water vapor analyzer is used. There are some inaccuracies to be expected in application of the oxygen consumption technique to a ventilation limited fire due to partial oxidation of the pyrolysis products where the heat release per $\mathrm{kg}$ of oxygen consumed may deviate from 13.1 MJ.

If only a fraction $\lambda$ of the fuel vapor is burned in a ventilation limited system and $(1-\lambda)$ escapes, as would be the case in a postflashover room fire, it is necessary to determine a new volume expansion factor $\alpha$. 


$$
\alpha=\frac{\mathrm{n}_{\mathrm{N}_{2}}^{\circ}+\mathrm{n}_{\mathrm{H}_{2} \mathrm{O}}^{\circ}+\mathrm{n}_{\mathrm{CO}_{2}}^{\circ}+\mathrm{Bn}_{2}^{\circ}+\mathrm{n}_{\mathrm{f}}^{\mathrm{s}}}{\mathrm{n}_{\mathrm{N}_{2}}^{\circ}+\mathrm{n}_{\mathrm{H}_{2} \mathrm{O}}^{\circ}+\mathrm{n}_{\mathrm{CO}_{2}}^{\circ}+\mathrm{n}_{\mathrm{O}_{2}}^{\circ}}
$$

where all of the incoming oxygen has been converted to combustion products and $n_{f}^{s}$ is the molar flow rate of the unburned fuel in the exhaust duct.

$$
\begin{aligned}
& \alpha=x_{\mathrm{N}_{2}}^{\circ}+\mathrm{x}_{\mathrm{H}_{2} \mathrm{O}}^{\circ}+\mathrm{x}_{\mathrm{CO}_{2}}^{\circ}+\beta \mathrm{X}_{\mathrm{O}_{2}}^{\circ}+\frac{\mathrm{n}_{\mathrm{f}}^{\mathrm{s}}}{\mathrm{n}_{\mathrm{O}_{2}}^{\circ}} \mathrm{x}_{\mathrm{O}_{2}}^{\circ} \\
& \alpha=1-\mathrm{x}_{\mathrm{O}_{2}}^{\circ}+\left(\beta+\frac{\mathrm{n}_{\mathrm{f}}^{\mathrm{s}}}{\mathrm{n}_{\mathrm{O}_{2}}^{\circ}}\right) \mathrm{x}_{\mathrm{O}_{2}}^{\circ}
\end{aligned}
$$

The fraction of the fuel vapor burned is given by

$$
\lambda=\frac{n_{f}^{0}-n_{f}^{s}}{n_{f}^{0}}
$$

where $n_{f}^{0}$ is the molar flow rate of fuel into the system. Also,

$$
n_{f}^{\circ}-n_{f}^{s}=R n_{2}^{\circ}
$$

where $\mathrm{R}$ is the molar ratio of the fuel to oxygen consumed.

The combination of equations (60) and (61) yields

$$
\frac{\mathrm{n}_{\mathrm{f}}^{\mathrm{s}}}{\mathrm{n}_{\mathrm{O}_{2}}^{\circ}}=\frac{1-\lambda}{\lambda} R
$$


so that equation (34) should be replaced by

$$
\alpha=1-x_{O_{2}}^{\circ}+\left[\beta+\frac{1-\lambda}{\lambda} R\right] x_{O_{2}}^{\circ}
$$

when there is unburned fuel in the exhaust.

For a fuel limited fire, where $\lambda=1$, equation (63) reduces to equation (34). For a ventilation limited fire, where $\emptyset=1$, equation (33) reduces to

$$
\dot{\mathrm{V}}_{\mathrm{A}}=\dot{\mathrm{V}}_{\mathrm{s}} / \alpha
$$

The quantity $\lambda$ could be determined by the relationship

$$
\lambda=\frac{\dot{Q}}{\dot{Q}+\dot{Q}_{f}-\dot{Q}_{C O}}
$$

where $\dot{Q}_{f}$ is the product of the volumetric flow rate in the stack, $\dot{V}_{S}$, and the heat of combustion per unit volume as determined by a hydrocarbon analyzer, and $\dot{Q}_{C O}$ is the product of the heat of combustion of $\mathrm{CO}$, the concentration of $\mathrm{CO}$ in the exhaust duct, and the volumetric flow rate of the exhaust gases.

Since $\dot{\mathrm{V}}_{\mathrm{s}}$ depends on $\lambda$ this determination may require several iterations. It is also important to recognize that in the case of zero or near zero concentrations that additional errors can come about due to 
partially oxidized pryolysis products which, like $\mathrm{CO}$, may not release 13.1 MJ/kg of oxygen consumed.

10. HIGH TEMPERATURE OXYGEN CELL

If a high temperature oxygen cell is used in conjunction with a high temperature sampling line and no filtering, so that the concentration of oxygen in the cell is equal to that in the duct, then the oxygen depletion is given by

$$
\emptyset=\frac{\mathrm{x}_{\mathrm{O}_{2}}^{\circ} \dot{\mathrm{V}}_{\mathrm{A}}-\mathrm{x}_{\mathrm{O}_{2}}^{\mathrm{s}} \dot{\mathrm{V}}_{\mathrm{s}}}{\mathrm{x}_{\mathrm{O}_{2}}^{\circ} \dot{\mathrm{V}}_{\mathrm{A}}}
$$

Eliminating $\dot{\mathrm{V}}_{\mathrm{S}} / \dot{\mathrm{V}}_{\mathrm{A}}$ from equations (33) and (66), the depletion is given by

$$
\varnothing=\frac{\mathrm{x}_{\mathrm{O}_{2}}^{\circ}-\mathrm{x}_{\mathrm{O}_{2}}^{\mathrm{s}}}{\mathrm{x}_{\mathrm{O}_{2}}^{\circ}+\mathrm{x}_{\mathrm{O}_{2}}^{\mathrm{s}}(\alpha-1)}
$$

Substituting equation (33) into equation (13) yields

$$
\dot{Q}=\frac{E^{\prime} X_{O_{2}}^{\circ} \dot{V}_{s}}{1 / \varnothing+\alpha-1}
$$

for the open system when the volume flow rate must be measured in the exhaust duct.

Substituting equation (67) into (68) yields 


$$
\dot{Q}=E^{\prime}\left(X_{O_{2}}^{\circ}-X_{O_{2}}^{s}\right) \dot{V}_{s} / \alpha
$$

In a closed system where $\dot{V}_{A}$ is measured directly, equation (67) can be substituted into equation (13) to yield

$$
\dot{Q}=\frac{\mathrm{E}^{\prime} \mathrm{x}_{\mathrm{O}_{2}}^{\circ}\left(\mathrm{x}_{\mathrm{O}_{2}}^{\circ}-\mathrm{x}_{\mathrm{O}_{2}}^{\mathrm{s}}\right) \dot{\mathrm{V}}_{\mathrm{A}}}{\mathrm{x}_{\mathrm{O}_{2}}^{\circ}+\mathrm{x}_{\mathrm{O}_{2}}^{\mathrm{s}}(\alpha-1)}
$$

If $C O$ production were taken into account, it would be necessary to substitute equation (33) into equation (17) rather than equation (13). Then equation (68) would become

$$
\dot{Q}=\left(1-\frac{E^{\prime \prime}-E^{\prime}}{E^{\prime}} \frac{1}{\emptyset}-1 \frac{1}{2} \frac{X_{C O}^{A}}{X_{O_{2}}^{A}}\right) \frac{E^{\prime} X_{O_{2}^{\circ}}^{\circ} \dot{V}^{\prime}}{\frac{1}{\phi}+\alpha-1}
$$

for the case where the volumetric flow rate was measured in the exhaust duct. Substitution of equation (67) into equation (71) yields

$$
\dot{Q}=\left[1-\left(\frac{E^{\prime \prime}-E^{\prime}}{2 E^{\prime}}\right)\left(\frac{\alpha x_{O_{2}}^{s}}{x_{O_{2}}^{\circ}-x_{O_{2}}^{s}}\right) \frac{x_{C O}^{A}}{x_{O_{2}}^{A}}\right] \frac{E^{\prime}\left(x_{O_{2}}^{\circ}-x_{O_{2}}^{s}\right) \dot{V}_{s}}{\alpha}
$$

In a closed system where $\dot{V}_{A}$ is measured directly, equation (67) can be substituted into equation (17) to yield

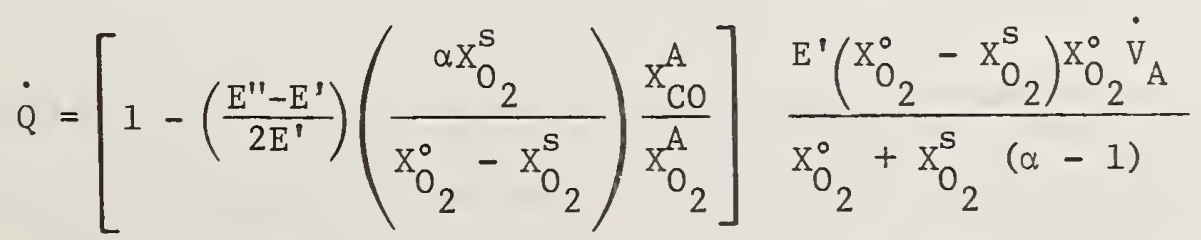

The concentration of oxygen $\mathrm{x}_{2}^{\mathrm{A}}$ in the gas sampling line to the c0 analyzer appears in both equations (72) and (73). Combining equations (8), (44), and (45) we find that 


$$
\frac{\mathrm{x}_{2}^{\mathrm{s}}}{\mathrm{X}_{\mathrm{O}_{2}}^{\mathrm{A}}}=1-\mathrm{x}_{\mathrm{H}_{2}}^{\mathrm{s}} \mathrm{O}
$$

Unless the water vapor concentration is measured in the exhaust duct, it is best to assume $\mathrm{x}_{\mathrm{O}_{2}}^{\mathrm{S}} / \mathrm{X}_{\mathrm{O}_{2}}^{\mathrm{A}}$ is equal to unity. The error incurred in the small correction term in equations (71) and (72) would not be expected to exceed 10 percent during expected operating conditions. Hence, the error in the heat release rate would be much less than 10 percent.

\section{SIMPLIFICATIONS}

Under some circumstances it is adequate to neglect $\mathrm{CO}$ and trap out the $\mathrm{CO}_{2}$ so that these two analyzers can be eliminated. Then $\mathrm{x}_{\mathrm{CO}_{2}}^{\mathrm{A}}=$ $\mathrm{X}_{\mathrm{CO}_{2}}^{\mathrm{A}}=0$. If it is further assumed that the ambient concentrations of $\mathrm{H}_{2} \mathrm{O}$ and $\mathrm{CO}_{2}$ can be neglected, equations (17) and (21) can be combined to yield

$$
\dot{Q}=\frac{\left(\mathrm{X}_{\mathrm{O}_{2}}^{\circ}-\mathrm{X}_{\mathrm{O}_{2}}^{\mathrm{A}}\right) \mathrm{E}^{\prime} \dot{\mathrm{V}}_{\mathrm{A}}}{\left(1-\mathrm{X}_{\mathrm{O}_{2}}^{\mathrm{A}}\right)}
$$

Equation (75) was used by Krause and Gann [3] in obtaining measurements of the heat release rate by oxygen depletion in the OSU calorimeter. When $\mathrm{CO}_{2}$ is trapped, $\mathrm{CO}$ is neglected and the system is open, such as in the bench top calorimeter with a canopy collection hood or for measurements of the heat developed by a room fire, it is necessary to determine 
$\dot{\mathrm{V}}_{\mathrm{A}}$ by equation (33). Assuming $(\alpha-1)=0.10$, with the above assumptions

$$
\dot{Q}=\frac{\left(\mathrm{X}_{\mathrm{O}_{2}}^{\circ}-\mathrm{X}_{\mathrm{O}_{2}}^{\mathrm{A}}\right)^{\mathrm{E}^{\prime} \dot{\mathrm{V}}_{\mathrm{s}}}}{\left(1-\mathrm{X}_{\mathrm{O}_{2}}^{\mathrm{A}}\right)(1+0.1 \emptyset)}
$$

In some cases, particularly in the burning of cellulosic materials in an adequate air supply where the production of $\mathrm{CO}$ can be neglected, the number of moles of oxygen consumed is approximately equal to the number of moles of $\mathrm{CO}_{2}$ produced. Hence

$$
\mathrm{n}_{2}^{\mathrm{s}}+\mathrm{n}_{\mathrm{CO}_{2}}^{\mathrm{s}} \approx \mathrm{n}_{\mathrm{O}_{2}}^{\circ} \text { and } \mathrm{n}_{\mathrm{CO}}^{\mathrm{s}}=0
$$

in the analyzer, provided that $\mathrm{CO}_{2}$ is not trapped, so that equation (8) can be written

$$
\mathrm{x}_{\mathrm{O}_{2}}^{\mathrm{A}}=\frac{\mathrm{n}_{\mathrm{O}_{2}}^{\mathrm{s}}}{\mathrm{n}_{\mathrm{N}}^{\circ}+\mathrm{n}_{\mathrm{O}_{2}}^{\circ}}
$$

Taking equations (1), (2), and (78) into account, equation (10) can be written

$$
\varnothing=\frac{\mathrm{x}_{\mathrm{O}_{2}}^{\circ}-\mathrm{x}_{\mathrm{O}_{2}}^{\mathrm{A}}}{\mathrm{x}_{\mathrm{O}_{2}}^{\circ}}
$$

Substituting this into equation (17) with the assumption that $\mathrm{X}_{\mathrm{CO}}^{\mathrm{A}}=$ $\mathrm{X}_{\mathrm{CO}_{2}}^{\circ}=\mathrm{X}_{\mathrm{H}_{2} \mathrm{O}}^{\circ}=0$ yields

$$
\dot{\mathrm{Q}}=\mathrm{E}^{\prime}\left(\mathrm{X}_{\mathrm{O}_{2}}^{\circ}-\mathrm{X}_{\mathrm{O}_{2}}^{\mathrm{A}}\right) \dot{\mathrm{V}}_{\mathrm{A}}
$$


This approximation was used in the investigation of the rate of heat release in room fires by Sensenig [2] where it was also assumed that the molar flow rate of air into the system was the same as that in the exhaust duct (i.e., $\dot{\mathrm{V}}_{\mathrm{A}}=\dot{\mathrm{V}}_{\mathrm{S}}$ ).

Table 1 provides a guide to finding the pertinent equations to be used for the various combinations of operating conditions.

\section{SUMMARY}

If $\mathrm{O}_{2}, \mathrm{CO}_{2}$, and $\mathrm{CO}$ concentrations are measured in the gas sampling lines and all other gases, vapors, and particulates except for nitrogen are trapped out, equation (17) can be used to calculate the rate of heat release.

$$
\dot{Q}=\left(\emptyset-\left(\frac{E^{\prime \prime}-E^{\prime}}{E^{\prime}}\right)\left(\frac{1-\varnothing}{2}\right) \frac{X_{C O}^{A}}{X_{O_{2}}^{A}}\right) E^{\prime} X_{O_{2}}^{\circ} \dot{V}_{A}
$$

where $E^{\prime}=17.2 \mathrm{MJ} / \mathrm{m}^{3}, E^{\prime \prime}=23.1 \mathrm{MJ} / \mathrm{m}^{3}$,

$$
\emptyset=\frac{\mathrm{x}_{2}^{\circ}-\mathrm{x}_{2}^{\mathrm{A}}\left(1-\mathrm{x}_{\mathrm{CO}_{2}}^{\circ}-\mathrm{x}_{\mathrm{H}_{2} \mathrm{O}}^{\circ}\right) /\left(1-\mathrm{x}_{\mathrm{CO}_{2}}^{\mathrm{A}}-\mathrm{x}_{\mathrm{CO}}^{\mathrm{A}}\right)}{\mathrm{x}_{\mathrm{O}_{2}}^{\circ}\left[1-\mathrm{x}_{\mathrm{O}_{2}}^{\mathrm{A}} /\left(1-\mathrm{x}_{\mathrm{CO}_{2}}^{\mathrm{A}}-\mathrm{x}_{\mathrm{CO}}^{\mathrm{A}}\right)\right]}
$$

and the ambient air concentrations of oxygen and carbon dioxide are determined from the equations 


$$
\begin{aligned}
& \mathrm{x}_{2}^{\circ}=\mathrm{x}_{\mathrm{O}_{2}}^{\mathrm{A}^{\circ}}\left(1-\mathrm{x}_{\mathrm{H}_{2} \mathrm{O}}^{\circ}\right) \\
& \mathrm{x}_{\mathrm{CO}_{2}}^{\circ}=\mathrm{x}_{\mathrm{CO}_{2}}^{\mathrm{A}^{\circ}}\left(1-\mathrm{x}_{\mathrm{H}_{2} \mathrm{O}}^{\circ}\right)
\end{aligned}
$$

if $\mathrm{CO}_{2}$ is not trapped, and by

$$
\mathrm{x}_{\mathrm{O}_{2}}^{\circ}=\mathrm{x}_{\mathrm{O}_{2}}^{\mathrm{A}^{\circ}}\left(1-\mathrm{x}_{\mathrm{K}_{2} \mathrm{O}}^{\circ}-\mathrm{x}_{\mathrm{CO}_{2}}^{\circ}\right)
$$

if $\mathrm{CO}_{2}$ is trapped. The concentrations $\mathrm{x}_{\mathrm{O}_{2}}^{\mathrm{A}^{\circ}}$ and $\mathrm{x}_{\mathrm{CO}_{2}}^{\circ}$ are measured in the analyzers prior to test and account for the water vapor, and in the latter case, the $\mathrm{CO}_{2}$ trapped in the sampling line. In many cases, the ambient concentration of $\mathrm{CO}_{2}$ can be neglected so that $\mathrm{x}_{\mathrm{CO}_{2}}^{\circ} \equiv 0$.

The formula for the ambient water vapor concentration

$$
\mathrm{X}_{\mathrm{H}_{2} \mathrm{O}}^{\circ}=\frac{\mathrm{P}_{\mathrm{H}_{2} \mathrm{O}}}{760}\left(\frac{\mathrm{H}}{100}\right)
$$

is discussed in section $V$.

If the incoming air is fully depleted of its oxygen, equation (56) should be substituted for equation (17) in order to determine the heat release based on the $\mathrm{CO}$ and $\mathrm{CO}_{2}$ concentrations. If a high temperature oxygen cell is used, then equation (17) should be replaced by equations (73) and (74). 
For closed systems, such as an enclosed calorimeter or the ASTM E 84 tunnel, where the inflow of air can be measured, $\dot{\mathrm{V}}_{\mathrm{A}}$ can be obtained directly. For open systems such as the bench top heat release rate calorimeter or the standard room fire test, it should be determined from equation (33)

$$
\dot{\mathrm{V}}_{\mathrm{A}}=\frac{\dot{\mathrm{V}}_{\mathrm{s}}}{1+(\alpha-1) \emptyset}
$$

The quantity, $\alpha$, can be calculated using equations (34), (36), (37), or (38) and (39) if the chemical composition of the pyrolysis products are known. This is usually not the case, however, so that an average value of $\alpha=1.1$ should normally be used. If a water vapor analyzer is used to measure the concentration of water vapor in the exhaust duct equation (53) can be used to determine $\dot{V}_{A}$ unless the oxygen is completely consumed, in which case equation (57) should be used. Equation (42) can be used to calculate $\dot{\mathrm{V}}_{\mathrm{S}}$. If it is necessary to correct for the density of the exhaust gases being different than that of air, the right-hand side of equation (42) should be multiplied by $\mathrm{W}_{A I R} / \mathrm{W}_{\mathrm{S}}$, where $\mathrm{W}_{\mathrm{AIR}}$ is the mass per mole of the incoming air and $W_{S}$ is the mass per mole of the exhaust gas given by equation (43). If there is unburned fuel other than $\mathrm{CO}$ in the exhaust gas, then equation (63) rather than (34) should be used to calculate $\alpha$.

If $\mathrm{CO}$ can be neglected and $\mathrm{CO}_{2}$ is trapped, equation (75) can be used to calculate the heat release rate. For those cases where it can be assumed that the number of moles of $\mathrm{O}_{2}$ consumed is equal to the 
number of moles of $\mathrm{CO}_{2}$ produced (e.g. complete combustion of cellulose), the heat release rate can be calculated from equation (80). $\mathrm{CO}_{2}$ does not need to be measured in this case but it must be permitted to flow through the oxygen analyzer.

\section{REFERENCES}

[1] Parker, W. J., An Investigation of the Fire Environment in the ASTM E 84 Tunnel Test, NBS Technical Note 945, August 1977.

[2] Sensenig, D. L., An Oxygen Consumption Technique for Determining the Contribution of Interior Wall Finishes to Room Fires, NBS Technical Note 1128, July 1980.

[3] Krause, R. F. and Gann, R. G., Rate of Heat Release Rate Measurements Using Oxygen Consumption, Journal of Fire and Flammability, Vol. 12, 117-130 (1980).

[4] Huggett, C., Estimation of Rate of Heat Release by Means of Oxygen Consumption Measurements, Fire and Materia1s, Vo1. 4, No. 2, 61-65 (1980).

[5] McCaffrey, B. J. and Heskestad, G., Combustion and Flame, Vol. 26, 125-127 (1976). 
14. NOMENCLATURE

A

a

$\mathrm{b}$

c

d

E

$E^{\prime}$

$E^{\prime \prime}$

e

f

g

$\mathrm{H}$

j

$\mathrm{k}$

$n_{i}$

$\mathrm{P}_{\mathrm{H}_{2} \mathrm{O}}$

$\dot{\mathrm{Q}}$

$\dot{Q}_{f}$

$\mathrm{R}$

$\mathrm{T}$

Cross sectional area of the exhaust $\operatorname{duct}\left(\mathrm{m}^{2}\right)$

stoichiometric coefficient for carbon

stoichiometric coefficient for hydrogen

stoichiometric coefficient for oxygen

stoichiometric coefficient for nitrogen

net heat of combustion per unit mass of oxygen consumed $(E=13.1 \mathrm{MJ} / \mathrm{kg}$ ) assuming carbon goes to carbon dioxide

net heat of combustion per unit volume of oxygen consumed referred to $20^{\circ} \mathrm{C}\left(\mathrm{E}^{\prime}=17.2 \mathrm{MJ} / \mathrm{m}^{3}\right)$ assuming carbon goes to carbon dioxide

net heat of combustion per unit volume of oxygen consumed referred to $20^{\circ} \mathrm{C}\left(E^{\prime \prime}=23.1 \mathrm{MJ} / \mathrm{m}^{3}\right)$ in the burning of carbon monoxide

stoichiometric coefficient for halogens

fraction of depleted oxygen going into the formation of co

number of moles of carbon monoxide produced per mole of reactant consumed

relative humidity of the ambient air (\%)

calibration factor equal to 1.00 for pitot static tube and 0.926 for bidirectional probe

ratio of average mass flow rate to centerline mass flow rate in duct

molar flow rate of species $i$

vapor pressure of water at ambient temperature (mm $\mathrm{Hg}$ )

total rate of heat production $(\mathrm{kW})$

product of the heat of combustion of exhaust gases and their flow rate $(\mathrm{kW})$

molar ratio of fuel to oxygen consumed

temperature of gas (K) 


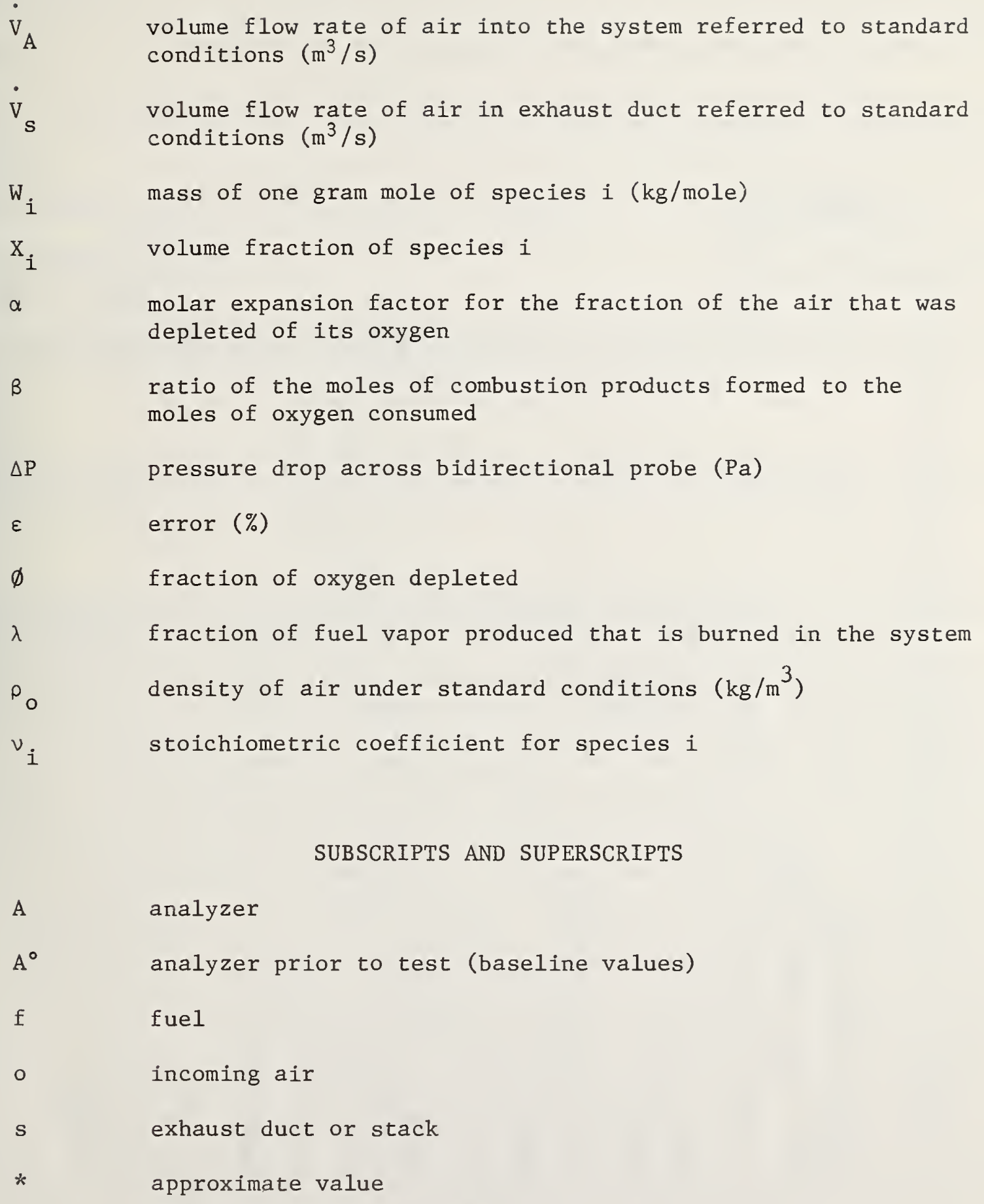


$b^{\infty} \stackrel{\sim}{\mathcal{V}}$

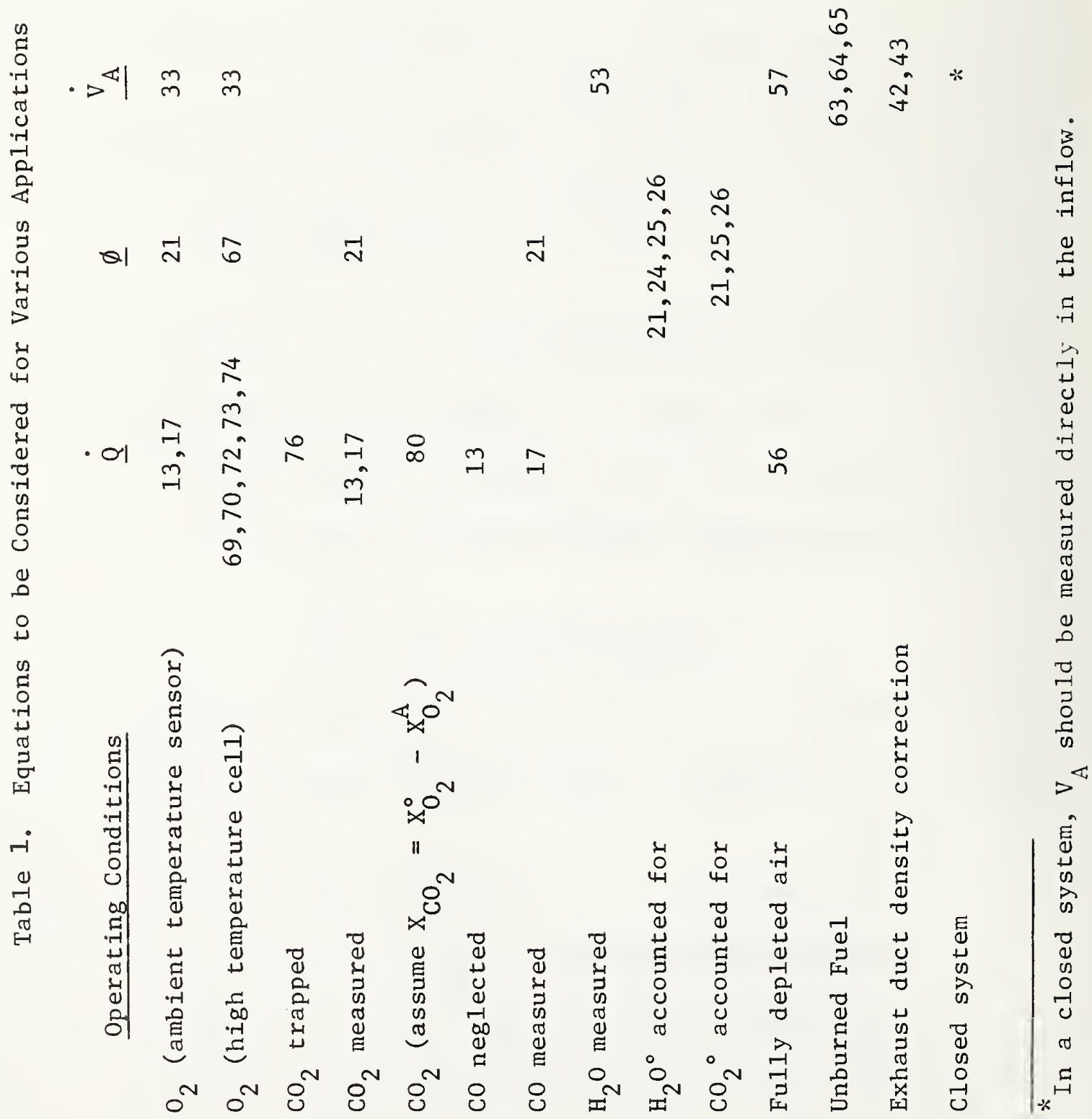


U.S. DEPT. OF COMM.

BIBLIOGRAPHIC DATA

SHEET (See instructions)
1. PUBLICATION OR REPORT NO.

NBSIR $81-2427-1$
2. Performing Organ. Report No.

3. Publication $D$ ate

March 1982

4. TITLE AND SUBTITLE

Calculations of the Heat Release Rate by Oxygen Consumption for Various Applications

5. $A \cup T H O R(S)$

W. J. Parker

6. PERFORMING ORGANIZATION (If joint or other than NBS, see instructions)

7. Contract/Grant No.

NATIONAL BUREAU OF STANDARDS

DEPARTMENT OF COMMERCE

WASHINGTON, D.C. 20234

8. Type of Report \& Period Covered

9. SPONSORING ORGANIZATION NAME AND COMPLETE ADDRESS (Street。City, State, ZIP)

10. SUPPLEMENTARY NOTES

[ Document describes a computer program; SF-185, FIPS Software Summary, is attached.

11. ABSTRACT (A 200-word or less foctual summary of most significant information. If document includes a significant bibliography or literoture survey, mention it here)

The oxygen consumption technique is emerging as a powerful tool for determining the heat release rate in a number of diverse fire test applications, including room fire tests, fire endurance tests, the ASTM E 84 tunnel test, and various heat release rate calorimeters. Depending upon the constraints of the test, the accuracy required, the availability of instrumentation and computational facilities, and the willingness to put up with experimental inconveniences, a number of instrumentation options have been considered--each of which require different calculational procedures. The purpose of this report is to develop the equations in a general way and show how to adapt them to various applications such as: closed systems versus open systems; trapping carbon dioxide before it reaches the oxygen analyzer, measuring it, or assuming that it is equal to the reduction in oxygen concentration; ignoring carbon monoxide or measuring it; accounting for the density of the exhaust gases or assuming that it is the same as for air; using a high temperature oxygen cell which measures the oxygen concentration in the exhaust duct directly or a paramagnetic analyzer for which corrections must be made for water vapor trapping; taking into account or ignoring the ambient concentration of water vapor and carbon dioxide; and, improving the accuracy for open systems by monitoring the water vapor in the exhaust duct. The equations developed here should be useful to anyone setting up a new system and will provide a means of calculating the errors which might be expected when simplified procedures are used.

12. KEY WORDS (Six to twelve entries; alphabetical order; capitalize only proper names; and separate key words by semicolons)

Calorimeters; fire tests; heat release rate; oxygen consumption; room fires

\section{AVAILABILITY}

X] Unlimited

$\square$ For Official Distribution. Do Not Release to NTIS

$\square$ Order From Superintendent of Documents, U.S. Government Printing Office, Washington, D.C. 20402.

X] Order From National Technical Information Service (NTIS), Springfield, VA. 22161
14. NO. OF PRINTED PAGES 41

15. Price $\$ 7.50$ 

